\title{
Türkiye'de Gazetecilerin Bilgi Gereksinimlerinin ve Arama Davranışlarının Değerlendirilmesi
}

\author{
Assessment of Journalists' Information Needs and \\ Seeking Behaviour in Turkey
}

\section{İnci ÖNAL*}

\section{Öz}

Araştırmanın amacı, Türkiye'de gazetecilerin bilgi gereksinimlerini ve arama davranışlarını ortaya çıkarmaktır. Ocak 2007 ile Haziran 2008 tarihlerinde gerçekleştirilen bu araştırmada, Türkçe olarak yayınlanan 31 ulusal günlük gazetede görev yapan 217 gazetecinin özellikleri, bilgi gereksinimleri, ilgileri, bilgi kaynaklarını ve bilgi merkezlerini kullanma amaçları saptanmıştır. Gazetecilerin araştırma alanlarının başında haberin yazımı ile ilgili bilgiler geldiğinden, bu doğrultuda geniş kapsamlı, güncel ve orijinal bilgiye en kısa zamanda ulaşmak istenmektedir. Yapısal değişimler, ekonomik güçlükler ve enformasyon teknolojisinin kullanımı, gazetecilerin bilgi gereksinimlerini ve bilgi arama davranışlarını değiştirmiştir. Gazetecilerin kütüphanelerde ve arşivlerde karşılaştıkları bilgi erişim engellerinin başında bilgiyebelgeye hemen erişememe, aranılan kaynağı bulamama, bilgi hizmetlerine yabancılık, öz bilgiye erişememe gibi sorunlar gelmektedir. Çalışmanın sonunda mevcut durumu iyileştirmek için bazı öneriler sunulmuştur. Böylece gelecekte bilgi erişimi kolaylaştıran sistemlerin hayata geçirilmesi beklenmektedir.

\footnotetext{
*Doç.Dr.; Hacettepe Üniversitesi Bilgi ve Belge Yönetimi Bölümü, 06800 Beytepe, Ankara (onal@hacettepe.edu.tr)
} 
Anahtar sözcükler: Kullanıcı araştırmaları, Bilgi gereksinimleri, Bilgi arama davranışı, Gazeteciler, Gazetecilik, Medya, Bilgi yönetimi, Türkiye

\begin{abstract}
The purpose of this research was to investigate the information needs and information seeking behaviour of working journalists in Turkey. It investigated characteristics, information needs, interests, sources and purposes, libraries used and services required by 217 journalists in 31 national Turkish daily newspapers, during the period among January 2007 and June 2008 by means of a conducted survey. Journalists have a need for large volumes of very current and authoritative information, and they felt urged to ask the required information very quickly. Throughout the time it seems that shifts in newspaper coverage, the changing economic conditions, and the information flood provided through the new information technologies altered journalists' information requirements and information seeking behaviour. Considered as well were the barriers against meeting information needs in libraries and archives - in terms of time, resources, education, access and information overload. Conclusively, several recommendations are made for improving the existing situation. Future developments involving the library as an intermediary between electronic networks and the newspaper organization offer promises for inhouse system designers to reach solutions to problems of accessibility and ease of use.
\end{abstract}

Keywords: User studies, Information needs, Information seeking behaviour, Journalists, Journalism, Media, Information management, Turkey

\title{
Giriş
}

Yaşamının her evresinde çevresiyle etkileşim halinde olan insan, sürekli bilgi edinme ve bilgi paylaşma süreci içindedir. Genelde "iletişim" olarak ifade edilen bu süreç, bilgilenmek, bilgilendirmek, ikna etmek, yönetmek, eğlenmek, hedef üzerinde etkin olmak, davranışları geliştirmek ve değiştirmek gibi birçok nedenle gerçekleşmektedir. Sözlü, yazılı ve/veya sözsüz bazı sembollerle kodlanan iletiler algılanıp, yorumlanarak kullanıldıktan sonra bilgiye dönüşmektedir. Bilginin iletildiği ölçüde önem kazanması, bilgi ve iletişimi birbirleriyle bütünleştirmektedir. Yazının ve matbaanın icadıyla yaygınlaşan bilgilenme, haber alma ve iletme hareketleri 
iletişim teknolojilerinin etkin kullanımıyla kitle iletişimini sağlayacak biçimde hızlı bir değişim geçirmiştir. Kişilerin bulundukları yerden ayrılmadan dünyada neler olup bittiğine dair bilgiye belli ölçülerde ulaşabilmeleri, onların yaşam biçimlerini etkilemekte ve algılamalarını değiştirmektedir. İçinde yaşadığımız bilgi çağının gereği olarak, teknolojik gelişmelerin büyük bir hızla bilgi sistemlerine uyarlanması ve bunu kullanacak insanlara yönelik kullanıcı araştırmalarının yapılması önem kazanmıştır.

Bilgi bilimleri alanında kullanıcı araştırmalarını kapsayan temel çalışmalar bilgi gereksinimlerinin saptanması, bilgi merkezlerinden hizmet beklentilerinin ortaya çıkarılması, bilgi arama davranışlarının incelenmesi, erişim sorunları ve benzeri konularda gün-den güne çeşitlenerek gerçekleşmektedir. Konuyla ilgili çalışmalar 1940'lı yılların sonlarında başlamış, 1960'ların sonunda kullanıcıyla ilgili bilgi arama modelleri oluşturulmuş (Paisley, 1968; Allen, 1969), 1980'li yıllarda hız kazanmış ve çeşitlenmiştir. Önceleri sisteme önem verilirken, zamanla kullanıcı odak noktası olarak kabul edilmiştir. Fen bilimleri, sosyal bilimler gibi genel konularda çalışanların bilgi gereksinimlerinin saptanmasından başlanmış, 1990'lardan sonra daha ayrıntıya inilerek meslek, bilim dalları, yaş grupları, coğrafi bölgeler ve benzerleri gibi çeşitli alanlarda çalışanları kapsayan kullanıcı araştırmaları yapılmıştır. Böylelikle insanların işleri, çalışma ortamları, bilgiye verdikleri anlam, bilgi gereksinimleri, bilgi arama davranışları, bilgiyi nasıl değerlendirdikleri, bilgi sağlayan sistemler, bilgi merkezlerinin gereksinimleri karşılamadaki yeterlilikleri, yapılacak düzenlemeler, etkili bilgi hizmetleri sunabilmek için gerekenlerin neler olduğu gibi çok çeşitli sonuçlar ortaya çıkarılmıştır. Zamanla, kişilerin bilgiyle ilgili ilişkilerini içeren konular daha da genişlemiştir. Bilgi gereksinimlerinin ifade edilişi, bilginin zihinde belirlenen tanımı, kişisel farklılıklar, bilgi arama ve kullanma özellikleri üzerinde çalışılan konular olmuştur. Sadece kütüphaneler, arşivler ve dokümantasyon merkezleriyle sınırlı kalınmaksızın elektronik ortamlar, bilgi sistemleri, kişiler, içsel süreçler, kullanıcının çevresi ve çalışma ortamı gibi pek çok unsurun kullanıcının bilgiyle ilişkisinde önemli olduğu anlaşılmıştır. Elde edilen sonuçlar sadece bilgi bilimlerinin gelişerek kullanıcılara daha kaliteli bilgi hizmetleri verilmesini değil, bilim dallarının ve meslek alanlarının 
gelişmesine de olumlu etkileri olmuştur. Benzer sonuçların değerlendirilerek hayata geçirilmesi bilgiye, bilime, bilmeye, kendini tanımaya, kurumu geliştirmeye ve gelecek nesillere yönelik daha faydalı sistemlerin uygulanmasına katkılar sağlamıştır.

Kitlelere haber ve bilgi iletmede aracılık eden her türlü basılı ve elektronik kitle iletişim araçları "basın" ve "medya" kelimeleriyle eşanlamlı olarak ifade edilmektedir. Haber özelliği taşıyan bir olay hakkındaki bilginin toplanması, yazılması, düzenlenmesi ve dağıtılması basın-medya hizmetlerinin temelini oluşturmaktadır (Tokgöz, 2006). Medya kuruluşlarının bir parçası olarak gazeteler, kâr amacı güderken hizmetlerini somut biçimde gazete olarak müşterilerine sunmaktadırlar. Gazetecilerin okuyucuyu tatmin etme isteğiyle, en son haberi elde ederek bunları tüm içeriğiyle doğru biçimde ve en kısa zamanda yorumlayarak sunmaları gerekliliği onları bilgi kaynaklarına yöneltmektedir. Yazılı, basılı, sözlü ve/veya elektronik ortamda depolanarak erişim sağlanan her türlü bilgi kaynağına yönelik çeşitli düzeylerde ve biçimlerde hizmet beklentisi, "gazetecilerin bilgi gereksinimlerinin saptanmasını ve bilgi arama davranışlarının ortaya çıkarılmasını" amaç edinen, burada sunduğumuz araştırmanın yapılmasına neden olmuştur. Bu çalışma yukarıda genel olarak belirtilenlerle birlikte, gazetecilerin bilgi ile ilişkisini içeren tüm konuları kapsamakta ve bilgi ve belge hizmetlerinin geniş kapsamını göstermektedir. Araştırmamızla, hizmet veren kütüphanecilerin ve arşivcilerin çalışma alanlarının genişlemesine; hizmet alan gazetecilerin bilgi gereksinimlerinin ve bilgi arama davranışlarının belirlenmesine; sayılanlarla bağlantıı olarak güncel gelişmeler doğrultusunda topluma daha kaliteli hizmetler sunulmasına katkıda bulunmak hedeflenmiştir.

\section{Gazetecilik ve Gazeteci}

Basın-medya kuruluşları varlık nedenleri olarak haber aktarırlarken temel toplumsal işlevleri de yerine getirmektedir Diğer kuruluşlardan farklı olarak; haber toplama, işleme ve yayıma hazırlama, denetim ve eleştiri, kamuoyu oluşturma, siyasal karar alma yönünden ikna etme, eğitme, eğlendirme, reklam, boş zamanları doldurma vb. işlemleri yürütmektedirler. Yazı işleri ve haber merkezleri yönetiminde; yerel, ulusal ve çeşitli ülkelerde bulunan muhabirlerin çalışmalarıyla 
güncel haberler toplanmaktadır. Ayrıca; aboneliği sürdürülen haber ajanslarından gelen haberler seçilmekte, seçilen haberler işlenip iletişim araçları kanalıyla medya ürünü olarak yayıma sokulmaktadır. Basının haber kaynakları arasında Cumhurbaşkanlığı, Başbakanlık, Parlamento, bakanlıklar, siyasi parti kuruluşları ve temsilcilikleri, sendika kuruluşları, emniyet ve jandarma birimleri, adliyeler, eğitim kurumları, üniversiteler, hastaneler, ticari kuruluşlar, kurumlar, kişiler vb. tarafından üretilen yazılı, basılı, sözlü, görüntülü ve elektronik olmak üzere bir veya birkaç unsuru bir arada veren bilgi kaynakları ve belgeler bulunmaktadır. Basın kuruluşları, buralardan haber ve bilgi toplamak üzere görevlendirilen muhabirler kanalıyla kendilerine haber akışı sağlamaktadırlar. Görevlerin yapısına göre çeşitlenen çalışma alanlarında, istihdam ücretli ve telifli olarak iki farklı biçimde gerçekleşmektedir.

İnsanlar gazeteler aracılığıyla yaşadıkları yere, ülkeye veya dünyaya yönelik olaylar, ürünler ve ilgiler hakkında bilgi almaktadırlar. Gazetelerin temel özellikleri arasında güncellik, doğruluk, nitelikli anlatım ve yorumlama, ilgi çekicilik, hitap edilen alanın kapsamı, yayın aralığı, kamuoyuna önderliği, hitap edilen kitleye etkisi gibi özellikler bulunmaktadır. Gazeteler pek çok niteliklerine göre ayrılırken, Bodur (1997, s. 14), Tokgöz (2006), Vural (1999, s. 39), Yüksel ve Gürcan (2001, ss. 12-13) başlıca gruplamayı şöyle yapmaktadırlar:

- $\quad$ İçeriklerine göre: Spor, ekonomi, siyaset, vb.;

- $\quad$ Boyutlarına göre: Normal, tabloid ve yarım boy;

- Yayın sıklıklarına göre: Sabah, akşam, haftalık, vb.;

- Yayın politikalarına göre;

- Yayın dillerine göre;

- Dağıtım yapılan alana göre: Yerel, bölgesel, ulusal, vb.;

- $\quad$ Hitap ettikleri kitlenin özelliklerine göre.

Yazılı, sözlü ve/veya elektronik basında gazetelerde yer alan haberlere yönelik çalışmaları yürüten kişiler "gazeteci" olarak tanımlanmaktadır. Bir gazete işletmesinde gazeteciler, idari ve teknik elemanlar birlikte görev yapmaktadır. Gazetenin özelliklerine göre farklılık göstermekle birlikte, bir gazetenin örgüt yapısı başlıca 
iki kısımdan meydana gelmektedir (Evliyagil, 1981; Gaillard, 1991; Tokgöz, 2006; Willis, 1988):

1. Yazı işleri birimi: Haberin araştırılıp yazıımasından başlayarak sayfaya yerleştirilmesi, gerekli düzenlemelerin yapılması ve basılmasına değin işlemleri yüklenmektedir. Bu birimde gazete sahibi, genel yayın yönetmeni ve yardımcıları, yazı işleri müdürü ve yardımcıları, servis şefleri, editörler, muhabirler, yazarlar, haber yazıcılar (redaktörler), grafikerler, ressamlar, karikatüristler ve benzeri diğer görevliler bulunmaktadır. Çalışmalarda başlıca konu alanları iç haberler kapsamında Başkent, Parlamento, Başbakanlık, bakanlıklar, siyasi partiler, adliye, spor, kent haberleri ve benzerleridir. Dış haberlerde ajanslardan ve muhabirlerden gelen haberler büyük önem taşımaktadır. Haberleri ve olayları yorumlayan başyazar, köşe yazarları, uzmanlık yazısı yazarları ve acil haber sorumluları bu birimde görev yapmaktadır.

2. İdare birimi: Gazetenin etkili sunumu ve kâr etmesi için çalışanlardan meydana gelmekte ve bu kapsamda reklam, tiraj, basım, veri işleme, muhasebe, pazarlama, halkla ilişkiler, teknik işler ve benzeri çalışmaları yüklenmektedir.

\section{Konuyla İlgili Çalışmalar}

Zihinsel durumu ifade eden bilgi gereksinimi değişmez bir olgu değil, dinamik bir kavramdır. Temelde kişinin bilgi yetersizliğini kabul ederek bilgilenmeye çalışması (Krikelas, 1983); herhangi bir sorunun çözümünde gereken bilgiye sahip olabilmek üzere teşebbüslerde bulunması (Dervin ve Nilan, 1986, s. 17); bilgi düzeyinde boşluklar, şüpheler, yetersizlikler ve çelişkiler olduğunu hissederek bunu ortadan kaldırmak istemesidir (Reneker, 1993). En kolay biçimde bilgiye erişim isteği, gereksinimlerin karşılanmasında en çok tercih edilen yol olmuştur (Krikelas, 1983, ss. 15-16). Önceleri nitelikli bilgi kişisel çabalarla toplanmış, görünen yetersizliklerle birlikte bilgi erişimin bedeli, kapsamı ve kalitesiyle ilgili artan beklentiler, bilgi-belge hizmetlerinin düzenlenmesini zorunlu hale getirmiştir. Örnek veya model olarak hizmet veren merkezlerde kullanıcıların bilgi gereksinimleri karşılanmıştır. Hizmetlerin biçimlenmesine kullanıcı grubunun kişisel özellikleri, psikolojik nedenler, tepkiler, davranışlar 
ve bunlara bağlı olarak ortaya çıkan işlemler etkili olmuştur (Wilson, 1996). Bulunulan çevre koşulları, teknolojik gelişmeler, ekonomik durum ve dıştan gelen çeşitli etkiler bilgi gereksinimlerinin karşılanmasını sağlayan yeni düzenlemelerin yapılmasını sağlamıştır.

Whatmore (1978) gazetecilerin bilgi ve belge merkezlerinden karşılamayı ümit ettikleri bilgi gereksinimlerini ve türlerini saptamıştır. Bunlar belirli bir haber veya makale isteğini, özel soruları, eldeki bilginin doğruluğunun kontrolünü, bir haberin daha önce yayınlanıp yayınlanmadığının incelenmesini, haberle ilgili en son bilgi isteğini, kişilerle ilgili bilgileri, olayların geçmişiyle ilgili haberleri, derinlemesine araştırmaları kapsamaktadır. Önemli bilgi üreticileri ve yoğun bilgi kullanıcıları olmaları nedeniyle 1980'li yılların ortalarından itibaren gazetecilerin bilgi gereksinimlerini ve bilgi arama davranışlarını anlamaya yönelik araştırmaların sayısı artmaya başlamıştır (Herron, 1986).

Ward, Hansen ve Mc Leod (1988) gazetecilerin üstlendikleri görevlerin, bilgi-belge kaynaklarının ve merkezlerinin kullanımını etkilediğini ifade etmişlerdir. Gazeteciler başarılı olacak yeni bir araştırmanın, önceden yayınlanmış araştırmaların incelenmesinin ardından gerçekleştiğini saptamışlardır.

1990'lardan itibaren İnternet, bilgisayar destekli gazetecilik (Computer Assisted Journalism - CAJ veya Computer Assisted Reporting - CAR) ve çok sayıda veri tabanının hizmete girmesiyle gazetecilerin elektronik kaynak kullanımındaki bilgi arama davranışları üzerine çalışmalar yoğunluk kazanmıştır (Fabritius, 1998; Garrison, 1996; Garrison,1997; Garrison, 1998; McKercher, 1995; Nicholas ve Willams, 1998; Stanbridge, 1992).

Joseph (1993) gazete kütüphanelerinin, bilgi erişimle ilgili verdiği hizmetlerle gazete işletmesinin bel kemiğini oluşturduğunu ifade etmektedir. Sunulan bilgi kaynağının güvenilirliği, elde edilme süresi ve özgünlüğü verilen hizmetlerin değerini artırmaktadır.

Nicholas ve Martin (1997) yaptığı görüşmelerle İngiliz gazetecilerin temelde doğrulama; güncel duyuru; araştırma; kavram arama, çarpıcı konuları bulmayı kapsayan beş alanda bilgiye gereksinim duyduklarını saptamıştır. Bilgi arama davranışları 
gazetenin niteliğiyle, uzmanlık alanlarının yapısıyla, ilgilenilen haber türüyle ve geçmişe yönelik bilgi isteğiyle biçimlenmektedir. Belirtilen bu süreci zaman sınırlaması, gereksinim duyulan bilgiyi ifade güçlükleri, bilgi kaynaklarına ve hizmetlerine erişim sorunları, bilgi yoğunluğu ve eğitim eksiklilikleri olumsuz biçimde etkilemektedir. Özellikle bilgi teknolojilerinin gazetecilere verilecek bilgi hizmetlerinin yapısını tamamen değiştireceği düşünülmektedir (Campbell, 1997; Nicholas ve Martin 1997, ss. 44-51).

Paul (1997) gelişen bilgi teknolojileri sayesinde gazetecilerin aracıya gerek duymaksızın doğrudan doğruya bilgiye erişim imkânı bulduklarını belirtmiştir. Bu durumda, sadece bilgi kaynaklarına ve bilgi merkezlerinde verilen hizmetlere ulaşamayanlar değil, daha kaliteli hizmet beklentisindeki gazetecilerin de en önemli rehberi ve eğitimcisi kütüphaneciler olacaktır.

Fabritius (1999) gazetecilerin bilgi gereksinimleri, kullanılan bilgi kaynakları, erişim sorunları ve gazetelerde yer alan bilgi merkezlerinin kullanımı üzerine geniş kapsamlı bir araştırma yapmıştır. Gazetecilerin bilgi arama davranışlarını etkileyen kavramların; gazetecilik kültürü, iletişim aracının kültürü, çalışma biriminin-bölümünün kültürü, uygulama prensipleri, haberin hazırlanması, bilgi arama ve bilgi erişim olduğunu saptamıştır.

Gazeteciler elektronik bilgi kaynaklarını ve hizmetlerini tarama yapmak, resmi ve özel kuruluşların raporlarına ulaşmak, yeni kaynaklara erişmek, diğer gazeteleri okumak ve mesleki iletişim kurmak amacıyla kullanmaktadırlar. Gerek yaşanan zaman dilimi içinde, gerekse eski tarihli bilgiye gereksinim duyulmaktadır. Gazeteciler istenen bilgiye erişim, arşivleme ve aynı bilgiye tekrar erişim güçlüğü, bilgi-belge erişim yöntemleri konusunda eğitimsizlik, erişilen bilgiyi kullanamama, yüksek ücretli bilgiye erişememe, gerekeni bulama-maktan kaynaklanan zaman kaybı gibi sorunlarla karşılaşmaktadırlar (Attfield ve Dowell, 2003; Chinn, 2001; Nicholas, William, Cole, ve Martin., 2000; Middleberg ve Ross, 2001; Paul ve Hansen, 2002; Poteet, 2000).

Anwar, Al - Ansari ve Abdullah (2004) Kuveyt'te çalışan 92 gazetecinin bilgi arama davranışları üzerine bir araştırma yapmışlardır. Gazetecilerin haber yazmak, yeni fikirler edinmek, gündemi 
izlemek ve haberde yer alacak bilgileri kontrol etmek için oluşan bilgi gereksinimlerini en kolay, doğru ve hızlı biçimde karşılarken kütüphaneleri ve arşivleri kullandıklarını belirtmiş̧erdir.

Gao ve Vaughan (2005) gazetelerinin hazırlanmasında İnternetin bilgi kaynağı ve merkezi olarak kullanımını Amerika Birleşik Devletleri, Kanada ve Çin örneğinde incelemektedir. Adı geçen yazarlar bilgi teknolojilerindeki gelişmelerin gazetelerdeki bilgi-belge hizmetlerinin yapısını değiştirdiğine dikkat çekmişler; gazetelerin gerek kütüphanesinde, gerekse arşivinde görev yapan bilgi-belge yöneticilerinin yüklendikleri sorumluluk alanlarının sürekli değişim ve gelişim içinde olduğunu belirtilmişlerdir.

Türkiye'de basın, yayın ve gazetecilik konularında çalışanların hızlı, tam, güvenilir ve doğru bilgiye gereksinim duyduklarına dair genel kapsamlı yayınlar ve yayınların içinde kısa bilgiler bulunmaktadır. Ancak, gazetecilerin bilgi gereksinimleri ve bilgi arama davranışları üzerine ayrıntılı araştırmalara rastlanmamaktadır. Çiçek (1993) gazetelerde bilgi ve belge merkezlerinin önemini belir-terek sunulan hizmetleri açıklamıştır. Alır (2001) Türk basınında bilgi erişim sorunlarını 6 ulusal gazetenin Ankara Temsilciliklerinde çalışan sarı basın kartı sahibi 68 gazeteciye 33 sorudan oluşan anketi, 28 Kasım 2000-20 Ocak 2001 tarihleri arasında uygulayarak incelemiştir. Bu çalışmada, gazetecilerin meslektaşlardan, bireysel koleksiyonlardan, İnternet ortamından ve son 30 yıla ait haberlerden etkilendiklerini saptamıştır.

Önal (2007) ayrıntılı literatür taraması ve kaynak incelemesi yaparak gazetelere haber sağlayan kaynaklar, bilgi erişim kaynakları, bilgi merkezlerine yönelik hizmetler hakkında açıklayıcı bilgi vermiştir. Aynı kapsamda, bilgi hizmetlerinin yapılanması ve kullanımı üzerine gerçekleştirdiği bu araştırmasında Önal, 6 ulusal gazetede bilgi merkezlerinin verdiği hizmetleri değerlendirmiş, geleceğe yönelik hizmetleri ve beklentileri ifade etmiştir.

Türkiye'de gazetecilerin bilgi gereksinimlerini, bilgi arama davranışlarını ve bilgi erişim sorunlarını ulusal düzeyde saptayan bir araştırmaya ise rastlanmamıştır. 


\section{Gazetecilerin Bilgi Gereksinimlerinin ve Bilgi Arama Davranışlarının Araştırılması}

Dünya çapında genellenen bulgularla, gazetecilere verilen bilgi hizmetlerini aydınlatmak üzere "konuyla ilgili çalışmalar" önceki bölümde sunulmuştur. $\mathrm{Bu}$ bölümde yer alan araştırmayla Türkiye'deki durumu saptamak amaçlanmıştır.

\section{Amaçlar}

Araştırmamızın amacı Türkiye'de gazetecilerin gerek basın mensupları, gerekse temel kullanıcı grubu olarak, bilgi gereksinimlerini ve bilgi arama davranışlarını ortaya çıkarmaktır. Bu doğrultuda gerçekleştirilen araştırmamızda:

1. Yazılı basının üyesi olarak çalışan gazetecilerin bilgi gereksinimlerini, bilgi arama davranışlarını ve bilgi kaynakları kullanımıyla ulaşmak istedikleri bilginin özelliklerini saptamak;

2. Gazetecilerin çalışmalarını destekleyen kurumları, yapıları ve ortamları kapsayan temel unsurları tanımlamak;

3. Bilgi merkezlerinde ve elektronik ortamlarda sunulan bilgi hizmetlerinin kullanım biçimlerini ortaya çıkarmak;

4. Gazetecilerin konumuzla ilgili olarak bilgi merkezlerinde karşılaştıkları engelleri göstermek;

5. Kişisel görüşlerin ve değerlendirmelerin yapılmasına olanak sağlayarak ülke çapında oluşturulacak bilgi politikasında, gazetecilerin bilgi kullanım özelliklerinin de tanımlamasına yardımcı olmak amaçlanmıştır.

\section{Araştırmanın Alanı, Kapsamı ve Yöntem}

Gerçekleştirdiğimiz araştırmanın alanını Türkiye'deki yazılı basının en önemli unsuru kabul edilen ulusal gazetelerde görev yapan gazeteciler oluşturmaktadır. Ulusal gazetelerin tamamını belirlemek amacıyla Basın Yayın ve Enformasyon Genel Müdürlüğü başta olmak üzere resmi kurumlar, Türkiye Gazeteciler Cemiyeti, ulusal gazeteleri listeleyen ve onlara erişimi sağlayan İnternet siteleri araştırılmıştır. İnternet sitelerinden: 
- http://www.e-gazeteler.com/

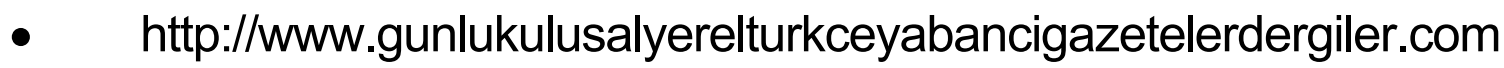

- http://turkishmedia.net/ araştırma alanının ve kapsamının belirlenmesinde çok yararlı olmuştur.

Listelerde bulunan ve Türkiye'de Türkçe olarak yayınlanan 31 ulusal günlük gazete, alfabetik sıralamaya göre şunlardır: Akşam, Anayurt, Birgün, Bugün, Cumhuriyet, Dünden Bugüne Tercüman, Dünya, Evrensel, Güneş, Hürriyet, Kurultay, Milli Gazete, Milliyet, Ortadoğu, Önce Vatan, Radikal, Referans, Sabah, Star, Şok, Takvim, Taraf, Tercüman, Türkiye, Vakit, Vatan, Yeni Asya, Yeniçağ, Yeni Mesaj, Yeni Şafak, Zaman.

Türkiye'de yayınlanan 31 ulusal günlük gazetenin merkezi genellikle İstanbul'da bulunmakta, genellikle Ankara'da Başkent temsilciliği, diğer illerde ise il temsilcilikleri açmaktadırlar. Temelde aktif iş ortamları ve sınırlı zamanları nedeniyle gazetecilere yönelik Türkiye genelinde araştırma yapmanın ve sonuç elde etmenin zorlukları düşünülmüştür. Mümkün olduğunca her ulusal gazetenin sadece merkezine değil, illerdeki temsilciliklerine de gidilerek karşılıklı görüşmelerle anketimizin yanıtlanmasını sağlayacak planlanma yapılmıştır. Ayrıca gazetecilerin elektronik posta adresleri de saptanmıştır. Ulusal gazetelerde görev yapan bütün gazeteciler, araştırma alanımızı oluşturmuştur.

Hazırladığımız anket soruları, 2006 yılının Aralık ayı boyunca gazetecilerin önerileriyle geliştirilmiştir. Bilgiye yönelik gereksinimleri, kullanımları, derecelendirmeleri ve birçoğunda diğer seçeneğiyle açıklamaları kaydeden toplam 21 sorudan oluşan anket geliştirilmiştir. Görev yapılan gazete, adı ve soyadı bilgisine gerek duyulmadığı, ancak anket sonuçları hakkında bilgi edinmek isteyenlerin aydınlatılacağı güvencesi verilmiştir. Ocak 2007-Haziran 2008 tarihleri arasında anket sorularımız gazetecilere iletilmiştir. Gazeteciler, İletişim Fakültesi öğrencileri, Bilgi ve Belge Yönetimi Bölümü öğrencileri ve konuya ilgi duyanlar araştırmamızın yürütülmesini desteklemişlerdir. Ulusal gazetelerde görev yapan gazeteci sayısındaki değişkenlik, elektronik posta yardımıyla anketleri gönderme kolaylığı, alınmayan yanıtlar nedeniyle birden çok yapılan anket 
gönderimleri, araştırma sürecinin uzunluğu ve benzeri nedenlerle ulusal gazetelerde görev yapan gazetecilerin kesin sayısını saptamak mümkün olamamıştır. Anket sorularıyla yanıt aldığımız 217 gazeteci araştırmamızın kapsamını oluşturmuştur.

Toplanan veriler betimleme yönetimi kullanılarak değerlendirilmiştir. Araştırma amacımız doğrultusunda mevcut durumlar, koşullar, özellikler aynen ortaya konmaya çalışılmış; böylece "ne ve nedir" sorularına cevap bulmaya yönelik durumlar arasındaki etkileşim (Kaptan, 2000, s.59) açıklanmıştır.

\section{Araştırmanın Uygulanması ve Bulgular}

Araştırmamıza katılan 217 gazetecinin \%36 (78 kişi)'sı kadın, \%64 (139 kişi)'ü erkektir. 20 ile 60 yaş ve üzeri olarak belirlenen yaş dağılımında çoğunluk \%37 (80 kişi) ile 20 - 29 yaş grubundadır. Yaşları 30 - 39 olanlar \% 9 (19 kişi), 40 - 49 olanlar \%17 (37 kişi), 50 - 59 olanlar \% 22 (48 kişi), 60 ve üzeri olanlar \%15 (33 kişi) oranlarındadır.

Anketi yanıtlayanların \% 57 (124 kişi)'si muhabir/yazar iken, \% 37 (80 kişi)'si editör, yazı işleri müdürü veya yardımcısı, \% 6 (13 kişi)'sı grafikerler, ressamlar, karikatüristler ve benzeri diğer görevlilerdir. \% 35 (76 kişi) İletişim Fakültesi, \% 31 (67 kişi) çeşitli lisans bölümleri, \% 29 (63 kişi) liselerden mezundur ve eğitim durumlarının dağılımı arasında önemli bir farklılık yoktur. Katılanların sadece \% 5 (11 kişi)'i yüksek lisans ve/veya doktora derecesine sahiptir. Çalışma alanları-konuları: \% 28 (61 kişi) iç haberler, \% 21 (45 kişi) köşe yazıları, \% 20 (43 kişi) spor, \% 16 (35 kişi) ekonomi, $\% 10$ (22 kişi) dış haberler, \% 5 (11 kişi) diğer olarak sıralanmıştır. Meslekteki çalışma süreleri şöyledir: \% 27 (59 kişi) $1-3$ yıl , \% 6 (13 kişi) 4 - 6 yıl, \% 5 (11 kişi) 7 - 9 yıl, \% 18 (39 kişi) 10 - 15 yıl, \% 44 (95 kişi) 16 ve daha fazla yıldır çalışmaktadır. Anketimizi yanıtlayarak araştırmamıza katılanlar sahip oldukları mesleki deneyimle bilgi gereksinimlerini ve kendilerine sunulan hizmetleri değerlendirebilecek niteliktedirler. 
Tablo 1. Gazetecilerin Bilgi Gereksinimleri ve Bilgi Arama Davranışları (n: 217)

\begin{tabular}{|c|c|c|c|c|c|c|c|c|}
\hline \multicolumn{9}{|c|}{ Bilgi Arama Davranışları } \\
\hline $\begin{array}{l}\text { Bilgi } \\
\text { Gereksinimleri }\end{array}$ & $\begin{array}{l}\text { O } \\
\frac{1}{0} \\
\frac{0}{2} \\
3 \\
0 \\
0 \\
0\end{array}$ & 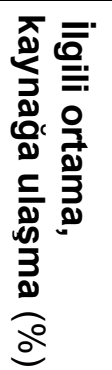 & 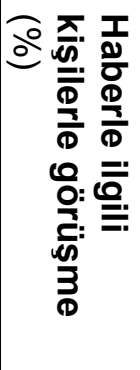 & 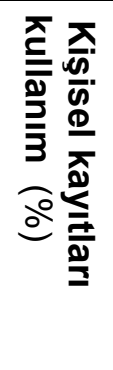 & 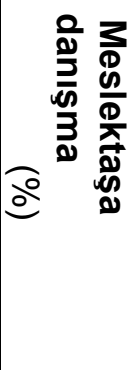 & 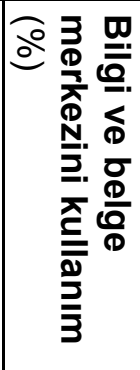 & 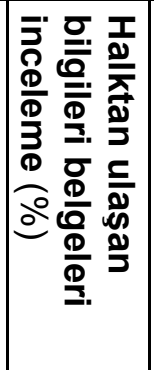 & $\frac{\text { 믐 }}{\frac{0}{10}}$ \\
\hline $\begin{array}{l}\text { Haberi } \\
\text { soruşturmak, } \\
\text { araştırmak }\end{array}$ & 1 & 80 & 75 & 70 & 55 & 32 & 63 & 52 \\
\hline $\begin{array}{l}\text { Haber metninin } \\
\text { yazımını sağlamak }\end{array}$ & 9 & 76 & 73 & 65 & 54 & 27 & 61 & 57 \\
\hline Gündemi izlemek & 6 & 73 & 71 & 60 & 50 & 26 & 57 & 55 \\
\hline $\begin{array}{l}\text { Haberin geçmişi } \\
\text { hakkında bilgi } \\
\text { toplamak }\end{array}$ & 3 & 38 & 35 & 55 & 38 & 57 & 40 & 38 \\
\hline $\begin{array}{l}\text { Gelecekteki } \\
\text { çalışmalar için yeni } \\
\text { fikirler edinmek }\end{array}$ & 9 & 26 & 27 & 48 & 29 & 59 & 54 & 30 \\
\hline $\begin{array}{l}\text { Tarih, yer, kişi, } \\
\text { yazım hataları ve } \\
\text { benzeri bilgileri } \\
\text { kontrol etmek }\end{array}$ & 7 & 23 & 22 & 40 & 29 & 73 & 42 & 30 \\
\hline $\begin{array}{l}\text { Haberle ilgili } \\
\text { fotoğraflara } \\
\text { ulaşmak }\end{array}$ & 3 & 34 & 32 & 39 & 24 & 44 & 30 & 28 \\
\hline $\begin{array}{l}\text { Kitap / yayın } \\
\text { hazırlamak }\end{array}$ & 1 & 24 & 18 & 21 & 20 & 24 & 18 & 22 \\
\hline Diğer & 8 & 18 & 15 & 18 & 17 & 21 & 20 & 17 \\
\hline
\end{tabular}

Gazetecilerin bilgi gereksinimleri ve bu doğrultuda geliştirdikleri bilgi arama davranışları birbirleriyle bütünleştirilerek Tablo 1'de gösterilmiştir. Tablo 1, gazetecilerin görevleri doğrultusunda hem bilgi gereksinimlerinin, hem de bilgiye ulaşma biçimlerinin nasıl şekillendiğini ifade etmektedir. Açık uçlu olan diğer seçeneğinde, "haberi birkaç kaynaktan doğrulama, muhalif görüşleri izleme, mevzuat, mahkeme 
kararlarına ulaşma ve benzeri nedenler" bilgi gereksinimlerini tanımlamıştır. Sayılan gereksinimler kişisel davranışları etkileyen bilgi arama davranışlarını çeşitlendirmektedir. Diğer seçeneğinde vurgulandığı gibi; bilgi arama davranışı bireysel farklılıklar gösterse de, çalışmaların etik değerlere uygun olarak biçimlendiği belirtilmiştir. Gazetecilerin ifade edemedikleri veya dışarıya vuramadıkları bilgi gereksinimleri, onların bilgi arama davranışlarını olumsuz yönde etkileyerek, başka konulara yönelmelerini sağlamaktadır.

Tablo 2. Gazetecilerin Bilgi Kaynakları Kullanımıyla Ulaşmak İstedikleri Bilginin Özellikleri (n: 217)

\begin{tabular}{|c|c|c|c|c|c|}
\hline \multirow[b]{2}{*}{ Bilgi Kaynakları } & \multicolumn{5}{|c|}{ Bilginin Özellikleri } \\
\hline & $\begin{array}{l}\frac{0}{3} \\
\frac{1}{0} \\
\frac{3}{3} \\
0 \\
\frac{0}{2}\end{array}$ & 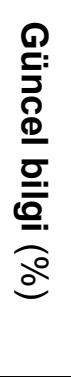 & 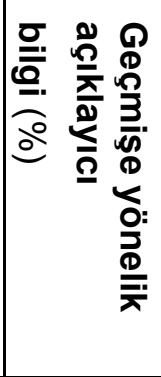 & 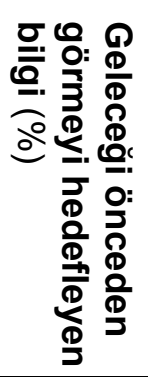 & 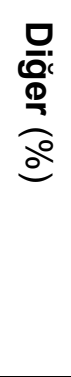 \\
\hline Resmi belgeler, kayıtlar & 61 & 77 & 75 & 47 & 45 \\
\hline Kişisel kayıtlar & 57 & 73 & 71 & 43 & 41 \\
\hline Haber ajansları & 55 & 98 & 36 & 44 & 42 \\
\hline İnternet olanakları & 54 & 97 & 41 & 38 & 40 \\
\hline $\begin{array}{l}\text { Telefon görüşmeleri, mülakatlar, } \\
\text { faksla gelen belgeler, mektuplar }\end{array}$ & 44 & 50 & 54 & 52 & 20 \\
\hline $\begin{array}{l}\text { Bulunduğum gazetede/kurumda } \\
\text { bulunan bilgi merkezleri }\end{array}$ & 34 & 20 & 48 & 40 & 28 \\
\hline $\begin{array}{l}\text { Bulunduğum gazete/kurum dışındaki } \\
\text { bilgi merkezleri }\end{array}$ & 31 & 22 & 44 & 35 & 23 \\
\hline Kupür veri tabanları & 28 & 21 & 51 & 21 & 19 \\
\hline $\begin{array}{l}\text { Diğer (Görsel - işitsel bilgi kaynakları; } \\
\text { televizyon, radyo yayınları vb.) }\end{array}$ & 11 & 21 & 10 & 8 & 5 \\
\hline
\end{tabular}

Tablo 2 gazetecilerin kullanmayı tercih ettikleri bilgi kaynaklarını göstermekle kalmamış, belirtilen bu kaynakları hangi özelliklerinden ötürü seçtiklerini de tanımlamıştır. Bu tablodaki diğer seçeneğine eklenen bilgi kaynakları ve onların özellikleri, gazetecilerin üzerinde 
çalışmakta oldukları araştırma dosyalarının yapısını, içeriğini, kaynağın adını ve kullanım nedenlerini ifade eden bilgiyi içermektedir.

Tablo 3. Gazetecilerin Çalışmalarını En Çok Destekleyen Unsurlar (n: 217)

\begin{tabular}{|c|c|c|c|c|}
\hline \multirow[b]{2}{*}{ Kurumlar - Yapılar } & \multicolumn{4}{|c|}{ Yöneltici Unsurlar } \\
\hline & ஓ웅 & 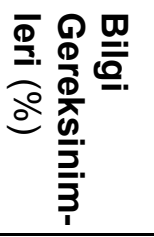 & 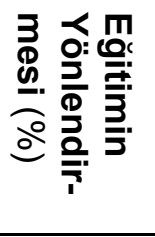 & $\begin{array}{l}\frac{0}{0 .} \\
\frac{0}{0} \\
\frac{0}{2} \\
0\end{array}$ \\
\hline \multicolumn{5}{|l|}{ Bilgi Merkezleri } \\
\hline Milli Kütüphane & 33 & 42 & 33 & 24 \\
\hline Üniversite Kütüphaneleri & 20 & 21 & 18 & 21 \\
\hline Kurum Kütüphaneleri & 18 & 22 & 16 & 16 \\
\hline Başbakanlık Devlet Arşivleri & 11 & 5 & 18 & 10 \\
\hline Resmi Daire Kütüphaneleri & 8 & 5 & 5 & 14 \\
\hline Diğer & 5 & 5 & 10 & -- \\
\hline Cevapsız & 5 & -- & - & 15 \\
\hline \multicolumn{5}{|l|}{ Arama Motorları } \\
\hline Google & 51 & 65 & 48 & 40 \\
\hline Yahoo & 20 & 15 & 15 & 30 \\
\hline Altavista & 13 & 5 & 18 & 16 \\
\hline Arabul & 6 & 5 & 8 & 5 \\
\hline Infoseek & 5 & 5 & 6 & 4 \\
\hline Diğer & 5 & 5 & 5 & 5 \\
\hline \multicolumn{5}{|l|}{ Haber Ajansları } \\
\hline Anadolu Ajansı & 39 & 31 & 58 & 28 \\
\hline İhlas Haber Ajansı & 28 & 32 & 28 & 24 \\
\hline Doğan Haber Ajansı & 7 & 11 & -- & 10 \\
\hline Medya Takip Merkezi & 6 & 9 & -- & 9 \\
\hline Avrasya Haber Ajansı & 5 & 7 & -- & 8 \\
\hline Reuters & 5 & 5 & 10 & - \\
\hline Cihan Haber Ajansı & 5 & 5 & -- & 10 \\
\hline Diğer & 5 & -- & 4 & 11 \\
\hline \multicolumn{5}{|l|}{ Kupür Veri Tabanları } \\
\hline Başbakanlık Kupür Arşivi & 36 & 40 & 43 & 25 \\
\hline Hürriyet Gazetesi Kupür Arşivi & 33 & 34 & 27 & 38 \\
\hline Zaman Gazetesi Kupür Arşivi & 21 & 21 & 20 & 22 \\
\hline Cumhuriyet Gazetesi Kupür Arşivi & 5 & 5 & 5 & 5 \\
\hline Diğer & 5 & -- & 5 & 10 \\
\hline
\end{tabular}


Tablo 3 gazetecilerin çalışmalarını destekleyen bilgi merkezi türlerini, arama motorlarını, haber ajanslarını ve kupür veri tabanlarını göstermekte olup, belirtilen bu kurumlara ve yapılara yöneltici unsurların etkisini ortaya çıkarmaktadır. Gazetecilerin bilgi gereksinimleri ve eğitimle kazanılan değerler, temel yöneltici unsurlar arasındadır. Diğer yanıtı kişisel düşüncelerle ve özel nedenlerle ismi verilen kurumları ve yapıları içermektedir.

Görev yapılan gazetede bilgi merkezlerinin (kütüphanelerin/ arşivlerin) varlığı ve genel kullanım derecesi saptanmak üzere bir soru yöneltilmiştir. Bu soruya verilen yanıtların \% 32 (70 kişi)'si bilgi merkezlerinin var olduğunu ve kullanıldığını, \% 28 (61 kişi)'i bilgi merkezlerinin varlığını ancak ilgili kişilerin kullanmadığını, \% 25 (54 kişi)'i bilgi merkezlerinin olmadığını, ancak olmasının istendiğini, \% 8 (17 kişi)'si bilgi merkezlerinin var olduğunu ve çok yararlanıldığını, \% 7 (15 kişi)'si bilgi merkezlerinin bulunmadığını belirtmiştir. Ortaya çıkan durum, gazetelerde \% 40 oranında bilgi merkezi varlığının, \% 60 oranında ise yokluğunun ifadesidir.

Tablo 4. Gazetecilerin Bilgi Merkezlerini (kütüphaneleri/arşivleri) Kullanma Nedenleri * (n: 217)

\begin{tabular}{|l|c|}
\hline Kullanımlar & Dağılım (\%) \\
\hline Gazetelerin ve dergilerin eski sayılarına ulaşmak & $141(65)$ \\
\hline Bilgi kaynaklarını okumak ve yararlanmak & $132(61)$ \\
\hline Merkezdeki kütüphanecinin/arşiv görevlisinin tarama yapmasını istemek & $113(52)$ \\
\hline Araştırma konularına yönelik yeni fikirler edinmek & $80(37)$ \\
\hline Bilgi kaynaklarını ödünç almak & $61(28)$ \\
\hline Veri tabanlarını taramak & $59(27)$ \\
\hline Interneti kullanmak & $11(5)$ \\
\hline Diğer & $35(16)$ \\
\hline
\end{tabular}

* Birden çok yanıt verilmiş ve sıralama yapılmıştır.

Tablo 4 gazetecilerin bilgi merkezlerini kullanma nedenlerini ortaya çıkarmaktadır. Dağılımdaki yüksek oranlar gazeteciler tarafından bilgi merkezlerinin kullanıldığının veya kullanılmak istendiğinin göstergesidir. 
Tablo 5. Gazetecilerin Elektronik Ortamda Sunulan Bilgi Hizmetlerini Kullanma Nedenleri * (n: 217)

\begin{tabular}{|l|c|}
\hline Kullanma Nedenleri & Dağılım (\%) \\
\hline Konuyla ilgili bilgiye ve belgeye güncel olarak erişmek & $133(61)$ \\
\hline İnternet üzerinden açık arşivlere ve kurumsal bilgiye erişmek & $120(55)$ \\
\hline İletişim ve haberleşmeyi sağlamak & $106(49)$ \\
\hline Vveri tabanlarını izlemek ve yeni veri tabanlarından haberdar olmak & $95(44)$ \\
\hline $\begin{array}{l}\text { Kütüphane web sayfası üzerinden veri tabanlarını ve katalogları } \\
\text { kullanmak }\end{array}$ & $56(26)$ \\
\hline Soruları elektronik ortamda iletmek ve yanıt almak & $50(23)$ \\
\hline Diğer (Fotoğraf elde etmek, tanıtım yapmak, vb.) & $35(16)$ \\
\hline
\end{tabular}

* Birden çok yanıt verilmiş ve sıralama yapılmıştır.

Tablo 5 gazetecilerin elektronik ortamda sunulan bilgi hizmetlerini kullanma nedenlerini ortaya koymaktadır. Yeni teknolojilerin bilgi kaynaklarının kendisini ve erişim şekillerini değiştirmesiyle, gazetecilerin de kaynakları kullanımları ve erişim şekilleri etkilenmiştir. Elektronik ortamdaki bilgi kaynaklarını kullanmayanların oranı son derece düşüktür. Birçok durumda orijinal metni elde etme ihtiyacı duyulsa bile, günümüzde bilgiye ve belgeye hızlı erişim öne çıkarak kaynakların çevrim içi formunun kullanıldığı ortaya çıkmıştır.

Tablo 6 yardımıyla gazetecilerin bilgi merkezlerinde (kütüphanelerde / arşivlerde) karşılaştıkları bilgi erişim engelleri gösterilmektedir. Belirlenen engeller genellikle hem gazetecilerin, hem de bilgi merkezlerinin yetersizliklerinden kaynaklanmaktadır. Temelde bilgi merkezlerinden kullanıcı gereksinimlerini daha iyi saptamaları ve gereksinimlere uygun hizmet vermeleri beklenmektedir. 
Tablo 6. Gazetecilerin Bilgi Merkezlerinde kütüphanelerde/arşivlerde) Karşılaştıkları Bilgi Erişim Engelleri * (n: 217)

\begin{tabular}{|l|c|}
\hline Bilgi Erişim Engelleri & Dağılım (\%) \\
\hline Bilgiye - belgeye hemen erişememe & $187(86)$ \\
\hline Arananların bilgi merkezlerinde (kütüphanelerde/arşivlerde) olmayışı & $167(77)$ \\
\hline Bilgiye erişim ve kullanma becerileri konusunda eğitim eksikliği & $122(56)$ \\
\hline $\begin{array}{l}\text { Bilgi mersonelin çalışmaları yeterince } \\
\text { destekleyememeleri }\end{array}$ & $104(48)$ \\
\hline Bilgi merkezlerinin çalışma saatleriyle uyum sağlanamaması & $81(37)$ \\
\hline $\begin{array}{l}\text { Işlenmiş (düzenlenmiş, özetlenmiş) bilgiye yönelik bireysel isteklerin } \\
\text { karşınmaması }\end{array}$ & $65(30)$ \\
\hline Yabancı dil engeli & $47(22)$ \\
\hline Bilgi merkezlerine gerek duymuyorum & $37(17)$ \\
\hline Bilgiye erişimde sorun yaşamıyorum & $25(12)$ \\
\hline Diğer(Bürokratik engeller, vb.) & $27(12)$ \\
\hline
\end{tabular}

* Birden çok yanıt verilmiş ve sıralama yapılmıştır.

Açık uçlu olarak hazırlanan anketimizin son sorusu ile gazetecilerin bilgi gereksinimleri, bilgi kullanım özellikleri ve bilgi merkezlerinden (kütüphanelerden / arşivlerden) beklentileri konusundaki görüşleri ve değerlendirmeleri saptanmıştır. Tablo 7'de belirtilenler gazetelerde karşılaşılan nitelik ve nicelik sorunlarını tanımlamaktadır. Gazetecilerin tartışılabilir değerlendirmeleri (İnternet bilgi merkezlerinin yerini almıştır), önyargıları (kütüphaneciden ve arşivciden bilgi hizmetleri almak onur kırıcıdır) olduğu, terimleri karıştırmakla kalmayıp kütüphanecilerle ve arşivcilerle örtüşmeyen düşünceleri (bilgi merkezlerindeki koleksiyonun sansürden etkilendiği düşünülmektedir) ortaya çıkmıştır. 
Tablo 7. Gazetecilerin Bilgi Gereksinimleri, Bilgi Kullanım Özellikleri ve Bilgi Merkezlerinden (Kütüphanelerden/Arşivlerden) Beklentileri Konusunda Görüşleri ve Değerlendirmeleri* (n: 217)

\begin{tabular}{|l|c|}
\hline Görüşler ve Değerlendirmeler & Dağılım (\%) \\
\hline İnternet, bilgi merkezlerinin yerini almıştır. & $155(71)$ \\
\hline $\begin{array}{l}\text { Bilgi merkezlerinin kullanımını engelleyen önyargılar bulunmaktadır: } \\
\text { Gazeteci bilgi ve belge hizmetlerinin kendisine ulaştırılmasını } \\
\text { bekleyemez, orijinal çalışmalar bireyselliği gerektirir, kütüphaneciden } \\
\text { ve arşivciden bilgi hizmetleri almak onur kırıcıdır, vb. }\end{array}$ & $143(66)$ \\
\hline $\begin{array}{l}\text { Kütüphaneciler / Arşivciler medyanın çalışma sistemini } \\
\text { bilmemektedirler. }\end{array}$ & $140(65)$ \\
\hline $\begin{array}{l}\text { Haberin arka planını çıkarmak ve haberi zenginleştirmek için bilgi } \\
\text { merkezlerinin kullanılmasını gerektiren ayrıntılı çalışmalar zor ve } \\
\text { zaman alıcı bulunmaktadır. }\end{array}$ & $105(48)$ \\
\hline Konunun uzmanlarına ve kişilere başvurulmaktadır. & $89(41)$ \\
\hline $\begin{array}{l}\text { Kütüphanelerin İnternet siteleri günün 24 saati kesintisiz, kolay erişimi } \\
\text { sağlamalıdır. }\end{array}$ & $74(34)$ \\
\hline $\begin{array}{l}\text { Bilgi merkezlerindeki koleksiyonun sansürden } \\
\text { düşünülmektedir. }\end{array}$ & $69(32)$ \\
\hline $\begin{array}{l}\text { Bilgi merkezlerinin kullanılmasındiği gerektiren araştırmacı gazeteciliğe } \\
\text { dayanan çalışmalar yüksek maliyetler nedeniyle tercih edilmemektedir. }\end{array}$ & $59(27)$ \\
\hline $\begin{array}{l}\text { Elektronik ortamdan gazetelerin eski sayılarına erişim olanakları } \\
\text { sağlanmalıdır. }\end{array}$ & $31(14)$ \\
\hline $\begin{array}{l}\text { Arşiv ve kütüphanelerde yetersiz hizmetler, zaman alıcı işlemler, talep } \\
\text { edilen bilginin bulunamaması ve sistemin karmaşıklığı gazetecileri } \\
\text { olumsuz yönde etkilemektedir. }\end{array}$ & $29(13)$ \\
\hline Görüşlerini bildirmeyenler ve değerlendirme yapmayanlar & $21(7)$ \\
\hline Diğer & $12)$ \\
\hline
\end{tabular}

* Birden çok yanıt verilmiş ve sıralama yapılmıştır.

Anketi yanıtlayarak, araştırmamıza katılanların \%87 (189 kişi)'si sonuçlar hakkında bilgi edinmek istediklerini belirtmişlerdir.

\section{Bulguların Değerlendirilmesi}

Araştırmamızla elde edilen bulgular doğrultusunda yapılan değerlendirmeler aşağıda verilmiştir:

1. Gazetecilerin bilgi gereksinimlerinin, bilgi arama davranışlarının ve bilgi kullanımlarının saptanmasına yönelik çalışmalar yapmak zordur. Bu alandaki kullanıcıların iş yoğunluğu, zaman 
harcamak istememeleri, araştırmalara katılmalarındaki isteksizlik ve çekimserlik araştırmaların yapılmasını zorlaştırmaktadır.

2. Bilgi ve belge yönetimi alanına neden konu olduklarının açıklanmasını isteyen gazeteciler, bireysel gizlilik güvencesinin ardından araştırmamıza katılmışlardır. Gazetecilere yönelik yapılan araştırmalarda betimleme yöntemi kapsamında görüşme, gözlem ve açık uçlu anket teknikleri çalışmaları kolaylaştırmaktadır.

3. Gazeteciler mesleklerine özgü farklı niteliklerinden dolayı araştırma konusu değil, araştırma yapan olmayı tercih ederler. Çok çeşitli konularda eğitim görenleri kapsadığından bilgi gereksinimleri diğer meslek gruplarıyla hem benzerlik, hem de farklılık gösteren gazeteciler, bilgiye gereksinim duymayı mesleki yetersizlik olarak niteleme eğilimindedirler.

4. Araştırmamıza katılan gazetecilerin özellikleri (cinsiyet, yaş, eğitim, görev, alan, mesleki deneyim) belirtilmesine rağmen, özel değerlendirmeler yapmayı gerektirecek farklılıklar yaratmamaktadır. Gazetecilerin özelliklerine göre ayrıntıya inen tablolarda oluşan dağılımlar istatistiksel açıdan farklılığa neden olacak derecede önemli değildir.

5. Bilgi gereksinimleri açık ve kesin biçimde ifade edilmeksizin, gereken bilgiye mutlaka ulaşımalıdır. Gazeteciler çalışmalarının doğal süreci içinde bilgiye gereksinim duyduklarından, bireysel olarak veya çalışma grupları içinde kendilerini bilgiye ulaştıran çeşitli yolları deneyerek bulduklarını ifade etmektedirler. Sadece resmi ve basılı kaynakları içeren iletişim değil; kişisel nitelikli, söze ve görüşe dayanan resmi olmayan iletişim de gazetecilerin bilgiyi aramalarında ve belgeye ulaşmalarında önem kazanmaktadır.

6. Güvenilir ve hızlı bilgi erişimin gerçekleştirilmesinde kişisel kayıtlar ve el altında bulundurulan bilgi kaynakları çok önemlidir. Bu durum gazetecilerin alışkanlıklarını, doğal olarak kolayı tercih edişlerini ve diğer bilgi kaynakları hakkındaki bilgisizliklerini ifade eden önemli bir göstergedir. 
7. Gazetelerde kurulan kütüphaneler ve arşivler yokluğu hissedilmeyen, varlığı çalışmaları önemli ölçüde kolaylaştıran bilgi erişim merkezleridir. Haberin geçmişiyle ilgili bilgi toplamak, güncel araştırmaları yürütmek ve geleceğe yönelik çalışmaları gerçekleştirmeye yardımcı olmak gazete bünyesindeki bilgi belge merkezlerinin temel görevleri arasındadır.

8. Gazetecilerin çalışmalarını destekleyen en önemli bilgi merkezi "Milli Kütüphane"dir.

9. En sık kullanılan çevrimiçi (online) araştırma ve haber kaynağı "Google" olarak belirlenmiştir.

10. Haber ajansları içerisinde "Anadolu Ajansı" gazetecilerin tamamına yakını tarafından kullanılmaktadır.

11. "Başbakanlık Kupür Arşivi" en yaygın kullanım alanına sahip kupür veri tabanıdır.

12. Bilgi gereksinimleri, eğitim ve mesleki deneyimler gazetecilerin çalışmalarını yönlendiren önemli unsurlardır.

13. Gazeteciler işlerini yürütebilmek için teknolojiyi izleme çabasındadırlar. Elektronik ortamları tanıyarak olabildiğince çeşitli bilgi kaynaklarına erişme ve onları kullanma isteği duymaktadırlar.

14. Orijinal belge, belge ile gazeteci arasında dolaysız bir ilişkinin kurulmasına imkân sağlamaktadır. Öncelikle orijinal belgenin kullanımı tercih edilmektedir. Ancak hız, güvenilirlik ve doğruluk sağlandığında gazeteci orijinal belgeye dayanan elektronik ortamdan edinilen çevrim içi formu kullanmaktadır.

15. Bilgi merkezlerinde çalışanlar medyanın işleyişini iyi bilmiyor. Araştırmamızın önemli bulgularından birisi de basın mensuplarının/gazetecilerin bilgi merkezleri ve hizmetleri ile ilgili düşünceleridir. Ankete katılan gazetecilerin belirttikleri düşünceler ve yaptıkları değerlendirmeler kütüphanecilerin ve arşivcilerin medyayı ve onun işleyişini iyi bilmedikleri yönündedir. Bilgi merkezleri ait oldukları ortamın amaçlarının gerçekleştirilmesinde kullanılan araçlardan biridir. Bu nedenle, hizmet veren ve alan her iki grubun birbirlerini daha iyi tanımalarıyla gerçekleştirilen bilgi ve belge hizmetleri 
gazetecilerin işlerini kolaylaştırmakla kalmayacak, gazetenin başarısını artıracaktır.

16. Basın, yayın, medya ve gazetecilik konularında deneyimli kütüphaneciler ve arşivciler gazetecilerin önemli rehberleridir. Aranılan bilginin belirsizliği, gizliliği ve ifade güçlükleri karşılıklı olarak iletişimi zorlaştırmaktadır. Ancak bilgi kaynakları ve bilgi merkezleri konusunda danışmanlık yapmakla kalmayıp eğitim de verebilen kütüphaneciler geleneksel görevlerini aşmışlardır. Gazetecilere bilgi erişimde kolaylıklar sağlayacak yöntemleri tanıtma ve uygulatma olanağına kavuşmuşlardır. Bu değişim bilgiye ve belgeye gereksinim duyan gazeteci ile söz konusu bilgiyi ve belgeyi değerlendirme, takip etme, ulaştırma ve erişim yöntemleri konusunda eğitim verebilen deneyim sahibi kütüphaneci arasında bilgi ortaklığı ve işbirliği kurulmasını sağlamıştır. Böylece her iki meslek grubu da mesleklerinde başarılarını artıracaklardır.

17. Bu araştırmanın basın, gazetecilik ve bilgi - belge hizmetleri alanlarında etkili olacağı düşünülmektedir. Anket sonuçlarına ilgi duyanlar bilgilendirilecektir. Ayrıca, gazeteciler yayınlandığında bu makaleyi okumak üzere yönlendirilecektir.

\section{Sonuç ve Öneriler}

Gereksinimlerin ortaya çıkarılması, açıklanması ve karşılanması zor ve karmaşık yapıya sahiptir. Bilgi gereksinimlerinin her zaman fark edilememesi, hatta kişinin bilgiye duyduğu gereksinimleri bastırmaya veya ertelemeye çalışması bile söz konusudur. Geniş çapta verilen hizmetler, kişilerin huzursuzlukla başlayan bilgi gereksinimlerini karşılayabilme süreci için onları yönlendirmektedir. Kütüphanecilik alanında yapılan değişik çalışmalarla gazetecilerin bilgi gereksinimlerinin saptanması, karşılanması ve bilgi arama davranışlarının değiştirilebileceği yolunda önemli aşamalar kaydedilmiştir. Burada gerçekleştirdiğimiz araştırmayla gazetecilerin bilgi kullanıcısı olarak nitelikleri, bulundukları çevre, bilgiyi nasıl algıladıkları, kullandıkları bilgi kaynakları ve karşılaştıkları engeller ortaya çıkarımıştır. Bunlar kütüphanecilerin, arşivcilerin, bilgi-belge uzmanlarının gelecekte sunacakları bilgi hizmetleri konusunda bilinçli olmalarını, konuyla ilgili 
eğitilmelerini, kendilerini geliştirmelerini ve planlama yapmalarını sağlayacaktır.

Araştırmamız sonucunda, gazetecilerin bilgi-belge merkezlerinden, kişilerden, kurumlardan ve elektronik ortamda geliştirilen sistemlerden bilgi sağladıkları saptanmışıı. Bilgi erişimde karşılaşılan engeller bildirilmiş ve ülke çapında etkili olması beklenen genel değerlendirmeler yapılmıştır. Araştırmamızın amaçları doğrultusunda gerçekleştirdiğimiz çalışmalarla ulaşıı̆ımız temel sonuçlar şunlardır:

- Dünya çapında genellenen bulgular gazetecilerin bilgi hizmetlerinde hız, doğruluk ve kolaylık istediklerini göstermiş̧ir.

- Gazeteciler yaş, eğitim, mesleki deneyim farkı göstermeksizin; mesleklerine özgü olarak genelde haber nitelikli ya da haberle bağlantılı bilgilere gereksinim duymakta, anında bilgi aramaya yönelmekte, mutlaka ve Israrla bilgi erişimi hedeflemektedirler.

- Güncel haberin ilgili kaynaktan, orijinal belgeye ulaşarak elde edilmesine yönelik bilgi arama davranışı tercih edilmektedir.

- Gazetecilerin bireysel farklııklarıyla bağlantılı olarak geliştirdikleri kendilerine özgü bilgi arama davranışları bulunmaktadır.

- Haberin, araştırmanın ve çalışmanın özelliğine bağlı olarak bilgi kaynakları kullanılmaktadır.

- Gazetecilerin çalışmalarını en çok destekleyen unsurların başında arama motorları gelmekte, bunu haber ajansları, kupür veri tabanları ve bilgi merkezleri izlemektedir.

- Milli Kütüphane en çok kullanılan bilgi merkezidir.

- $\quad$ Bilgi merkezlerini kullanma nedenlerinin başında, gazetelerin ve dergilerin elektronik ortama kaydedilmemiş eski sayılarına ulaşma isteği yatmaktadır. Bu neden, Milli Kütüphane'nin en çok kullanılan bilgi merkezi olmasını sağlamıştır.

- İletişim teknolojilerinin kullanımı bilgi merkezlerinde sunulan hizmetleri geliştirmektedir. 
- Gazetecilerin bilgi merkezlerini kullanmalarını ve bilgi hizmetlerine erişmelerini engelleyen önyargıları bulunmaktadır.

- Gazetecilerin bilgi merkezlerini kullanmalarını ve bilgi hizmetlerine erişmelerini engelleyen önyargılar gerek kütüphaneleri ve arşivleri, gerekse bilgi hizmetlerini yeterince kullanmamalarından kaynaklanmaktadır.

- Gazetecilere sunulan ve önerilen bilgi hizmetleri, onların önyargılarını olumlu yönde değiştirmektedir.

- Bilgi ve belge uzmanlarının gazetecilerin çalışma grupları içinde aktif görevler yüklenmeleri, bu alanda olumlu gelişmelere neden olacaktır.

- $\quad$ Araştırmamız sonucunda ortaya çıkan bulgular, yapılan değerlendirmeler ve varılan sonuçlar ülke çapında oluşturulacak bilgi politikasında gazetecilerin bilgi kullanım özelliklerinin tanımlanmasında gereken yardımları sağlayacaktır.

Bilgisayarlar 1970'li yıllarda gazetecilik alanına yazı yazmak ve haberin yayına hazırlanması amaçlarıyla girmiştir. 1980'lerde gazete kupürlerinin elektronik ortamda dosyalanması ve saklanması gerçekleştirilmiştir. 1990'larda çok sayıda veri tabanı ve İnternet ortamı gazetecilerin hizmetine girmiştir. 2000'li yıllarda gazetecilik bilgi ve becerilerinin yeni iletişim teknolojileriyle bütünleşmesi bilgisayar destekli gazetecilik ve İnternet gazeteciliğinin yaygınlaşmasını sağlamıştır. Elektronik ortamda hazırlanan ticari İnternet servisleri ve veri tabanları haberin önceden yayınlanıp yayınlanmadığına, yayınlandıysa içeriğinin ne olduğuna, doğruluk kontrolünün sağlanmasına, ilgili kişiler hakkında bilgi edinmeye, yeni haberler için fikir üretmeye, belgelere ulaşmaya, gazeteleri incelemeye, yeni bilgiye ulaşmaya, farklı kaynakları bir arada görmeye ve benzeri birçok bilgiye hızlı erişim imkânı yaratmıştır. Gazeteciler için sayısız yararlarına rağmen İnternet, elektronik kaynaklar ve veri tabanları bazı sorunları da beraberinde getirmektedir. Sorunlar güvenilirliğin sağlanamaması, kaliteli hizmetlere ulaşılamaması, tekrar erişim güçlükleri, arşivleme yetersizlikleri, doğru anahtar kelime ile tarama yapılmaması, eğitim eksiklikleri ve benzeri nedenlerle yaşanmaktadır. 
Çağdaş gelişmeler gazetelerde bilgi - belge hizmetleriyle bütünleşen elektronik kaynakların kullanımını zorunlu hale getirmektedir. Bu durum gazetelerde bilgi ve belge hizmetlerini verecek merkezlerin varlığı veya var olanların sürdürülmesi konusunda tartışmaların yaşanmasına neden olmaktadır. Burada gerçekleştirdiğimiz araştırma sonuçlarına göre, tartışmaların şu sebeplerden kaynaklandığı ortaya çıkmıştır:

- İletişim teknolojilerinin yardımıyla kişisel bilgi erişim yöntemlerinin yaygınlık kazanması;

- Bilgi merkezlerinden edinilen bilginin özgün ve güncel olamayacağına dair kuşkuların belirmesi;

- Basın kuruluşlarında bilgi kaynakları sağlama, bilgi arama davranışları geliştirme ve eğitim amaçlı bütçenin azaltııması;

- Gazetecilikte etkileşimli haber ortamlarının yaygınılı kazanması;

- Üst yöneticilerin idari yapıyı oluştururken bilgi - belge akışını düşünmeksizin, gazeteci bakış açısıyla, sadece özgün haberin sunulmasına yönelik düzenlemeler yapmalarıdır.

Basında güven duygusu yaratmanın koşulu doğru, dürüst, güncel, güvenilir haber kaynağı olarak algılanmayı gerektirmektedir. Aynı koşullar ve beklentiler bilgi ve belge hizmetlerinin temel amaçları arasında da bulunmaktadır. Gerek kütüphanecilerin, gerekse arşivcilerin basın - yayın - medya hizmetlerini, çalışma sistemlerini ve ulaşılmak istenilen hedefleri yakından tanımaları gerekmektedir.

$\mathrm{Bu}$ makale kapsamında gerçekleştirilen araştırmayla elde edilen bulgular, yapılan değerlendirmeler ve varılan sonuçlar gazetecilerin bilgi gereksinimleri, bilgi arama davranışları, bilgi kaynakları kullanımları, bilgi erişimde karşılaşılan engeller, kişisel görüşler ve değerlendirmeler hakkındadır. Belirtilenlerin ardından gazetecilerin bilgi kullanıcıları, bilgi kaynağı ve bilgi üreticisi nitelikleri düşünülerek şunlar önerilebilir: 
- Gazetecilere yönelik bilgi-belge hizmetleri modeli geliştirilmelidir.

- $\quad$ Gazetecilere bilgi hizmetlerini tanıtacak, bilgiye - belgeye en kısa zamanda erişim yollarını öğretecek kullanıcı eğitim programları uygulanmalıdır.

- $\quad$ Kütüphaneciler ve arşivciler basın, yayın ve medya alanında çalışmaya başlamadan önce gazetecilerin bilgi gereksinimleri ve bilgi arama davranışları hakkında bilgi sahibi olmalıdır.

- Gazetelerin hem tarihi, hem de güncel değerinden dolayı, onların tüm sayılarına erişimi sağlayacak düzenlemeler yapılmalıdır. Özellikle ulusal günlük gazetelerin toplanması, düzenlenmesi ve erişimi için bu görevi Milli Kütüphane yüklenmelidir.

Ortak çalışma alanı "bilgi" olan bilgi - belge uzmanlarının ve gazetecilerin birlikte çalışmaları hizmetlerin ve araştırmaların verimini artıracaktır.

\section{Kaynakça}

Alır, G. (2001). Türk basınında bilgi erişim sorunları. Yayınlanmamış bilim uzmanlığı tezi, Hacettepe Üniversitesi, Ankara.

Allen, T.J. (1969). Information needs and uses. Annual Review of Information Science and Technology, 4(1), 3-29.

Anwar, M. A., Al-Ansari, H. and Abdullah, A. (2004). Information seeking behaviour of Kuwaiti journalists. Libri, 54(4), 228-236.

Attfield, S. ve Dowell, J. (2003). Information seeking and use by newspaper journalists. Journal of Documentation, 59(2), 187-204.

Bodur, F. (1997). Yerel basında yönetim ve örgüt yapısı. Eskişehir: Açıköğretim Fakültesi Yayınları, No: 556.

Campbell, F. (1997). Journalistic construction of news: Information gathering. New Library World, 98(1133), 60-64.

Chinn, L.A. (2001). Information seeking behaviour and needs of journalists in context. Yayınlanmamış bilim uzmanlığı tezi, University of North Carolina at Chapel Hill. 
Çiçek, N. (1993). Gazete işletmelerinde belge-bilgi hizmetleri. Yayınlanmamış bilim uzmanlığı tezi, İstanbul Üniversitesi, İstanbul.

Devrin, B. ve Nilan, M. (1986). Information needs and uses. Annual Review of Information Science and Technology, 21, 3-33.

Evliyagil, Ş. (1981). Gazete yayımlama yöntemleri. Ankara: Ajans Türk.

Fabritius, H. (1998). Information seeking in the Newsroom. Application of the cognitive framework for analysis of the work context. Information Research, 4(2). 29 Temmuz 2008 tarihinde http://informationr.net/ir/4-2/isic/fabritiu.html adresinden erişildi.

Fabritius, H. (1999). Information seeking behaviour of journalists. 29 Temmuz 2008 tarihinde http://www.uta.fi/ lihafa/jan99sem.html adresinden erişildi.

Gaillard, P. (1991). Gazetecilik. (M.S. Şakiroğlu, Çev.). İstanbul: İletişim Yayınları.

Gao, Y. ve L. Vaughan. (2005). Web hyperlink profiles of news sites: A comparison of newspapers of USA, Canada, and China. Aslib Proceedings, 57(5), 398-411.

Garrison, B. (1996). Online service and the Internet: Computer assisted reporting in newsroom in 1995. 1 Ağustos 2008 tarihinde http://www.miami.edu/com/car/knoxvill.htm adresinden erişildi.

Garrison, B. (1997). Computer assisted reporting story and project topics 1995-96. 1 Ağustos 2008 tarihinde http://www.miami.edu/com/car/stpete.htm adresinden erişildi.

Garrison, B. (1998). Computer assisted reporting. Mahwah, NJ: Lawrence Erlbaum Assoc Inc.

Herron, N. L. (1986). Information-seeking behavior and the perceptions of information channels by journalist of two daily metropolitan newspapers. Yayınlanmamış doktora tezi, University of Pittsburgh, Ann Arbor, MI . UMI Number: 8702068.

Joseph, R. (1993). How Indian journalist use libraries. Information Development, 9(1-2), 70-75. 
Kaptan, S. (2000). Bilimsel araştırma ve istatistik teknikleri. (12. bs.). Ankara: Bilim Yayınları.

Krikelas, J. (1983). Information seeking behavior: Patterns and concepts chart. Drexel Library Quarterly, 19(Spring), 5-20.

McKercher, C. (1995). Computers and reporters. Canadian Journal of Communication, 20(2), 20-32.

Middleberg, D ve Ross, S.S. (2001). The Seventh Annual Middleberg/Ross survey of media in the wired world: Journalists' use of Internet at all categories. 1 Ağustos 2008 tarihinde http://www.middleberg.com/middlebergnews/view_pressrelease.cf $m$ ?pressrelease_index $=496$ adresinden erişildi.

Nicholas, D. ve Martin, H. (1997). Assessing information needs: A case study of journalists. Aslib Proceedings, 49(2), 43-52.

Nicholas, D. ve Willams, P. (1998). Journalism and the Internet: Prefieldwork literature review. City University. 29 Temmuz 2008 tarihinde http://www.soi.city.ac.uk/-pw/ji_lit.html adresinden erişildi.

Nicholas, D., William, P. E., Cole, P. ve Martin, H. (2000). The impact of the Internet on information seeking in the media. Aslib Proceedings, 52(3), 98-114.

Önal, H.I. (2007). Haberin geleceği: Gazetelerle ilgili bilgi hizmetlerinin yapılanması ve kullanımı. Bilgi Dünyası, 8(1), 99-122.

Paisley, W. (1968). Information needs and uses. Annual Review of Information Science and Technology, 3(1), 1-30.

Paul, N. (1997). Media libraries and new media. 29 Temmuz 2008 tarihinde http://www.poynter.org/research/nr/nr_libnm.htm adresinden erişildi.

Paul, N. ve Hansen, K.A. (2002). Reclaiming news libraries. Library Journal, 127(6), 44-46.

Poteet, A.R. (2000). Newspaper journalists' information seeking behavior with online information sources. Yayınlanmamış bilim uzmanlığı tezi, University of North Carolina at Chapel Hill. 
Reneker, M.H. (1993). A Qualitative study of information seeking among members of an academic community: Methodological issues and problems. Library Quarterly, 63(3), 487-507.

Stanbridge, R. (1992). Journalists begin to embrace online databases. Information World Review, 76(December), 46-48.

Tokgöz, Oya. (2006). Temel gazetecilik. Ankara: İmge Kitabevi.

Vural, M.A. (1999). Yerel basın ve kamuoyu. Eskişehir: T.C. Anadolu Üniversitesi Yayınları No: 1141.

Ward, J., Hansen, A.K. ve McLeod, D.M. (1988). The news library's contribution to news making. Special Libraries, 79(2), 143-147.

Whatmore, G. (1978). The modern news library. London: The Library Association.

Willis, J. (1988). Surviving in the newspaper business. New York: Praeger Publishing.

Wilson, T.D. (1996). Information behaviour: An inter - disciplinary perspective. Information Seeking in Context, 14-16 August, Tampere, $1-11$.

Yüksel,E. ve Gürcan, H.I. (2001). Habercinin el rehberi. Eskişehir: Anadolu Üniversitesi Yayınları. 